\title{
Crisis leadership: Evaluating our leadership approaches in the time of COVID-19
}

\section{Carol Mutch}

The current COVID-19 pandemic has provided the world with a range of crisis leadership case studies as nations' leaders approach control of, and communication about, the virus in dramatically different ways. Drawing on the literature and the author's post-disaster and post-crisis studies, this reflective piece offers a framework for analysing and evaluating leadership responses to the current crisis in order to strengthen our ability to deal with future crises. The focus of this article is on the development of a set of crisis leadership attributes and how we might use these to evaluate our own leadership roles as well as the wider work we do in leadership development, assessment, and evaluation.

\section{Introduction}

My interest in crisis leadership arose as I conducted research in post-disaster settings. As a Canterbury resident, I found myself living through the 2010-11 earthquake sequence and multiple aftershocks. I followed five school communities as they responded to the earthquakes and subsequent events. One of the key themes to emerge from 
the study was the way in which the principal's role changed from educational leader to crisis manager. After the Canterbury study, I spent time in other post-disaster and post-crisis communities in New Zealand, Australia, Japan, Nepal, Samoa, and Vanuatu. Not only did I interview principals but, depending on the context, also community, business, and political leaders. As time went by, I was able to refine my original findings using data from these varied settings. It was heartening to find that, while the experiences of leaders in these diverse contexts might vary owing to local circumstances, they did not vary in substance. The way in which the crisis cycle played out was remarkably similar and the ways in which effective crisis leaders responded to the events resonated across the geographic, economic, and cultural boundaries. My aggregated findings confirm that crisis leadership differs from everyday leadership practices because it requires leaders to deal with the immediacy and complexity of the precipitating event and the uncertainty of the constantly changing circumstances as they lead their organisation from response to recovery and beyond (Mutch, 2015a, 2015b, 2020, forthcoming; Mutch et al., 2020).

The article begins by briefly discussing crisis-leadership literature. From an early literature review (Mutch, 2015a), I developed a crisis-leadership attribute model which I used to analyse my Canterbury study and then refined as I added data from the wider crisis settings. The model is now being used in fields as diverse as emergency management, principal development, and organisational trauma. The attributes model is shared here as a tool that can be used to complement our varying roles as leaders or in leadership development, assessment, and evaluation. I provide some examples of how the model played out in practice across the varying contexts I investigated. Next, I further discuss the model using findings from the literature and my studies. I conclude by posing evaluative questions to 
use in settings where the evaluation of leadership in times of crisis is an important priority. The aim is that this framework will enable us to better understand and untangle the complexity of crisis leadership in these unprecedented times.

\section{Crisis leadership: Brief literature review}

Gandolfi and Stone (2016) claim that leadership is a topic that is over-researched but largely misunderstood. While there are contested views on what effective leadership is, they note that we are more likely to recognise what it is not, as less effective leadership, "occurs far too often and, as a result, people, organisations, communities and even societies are adversely affected" (p. 216). It its simplest form, Gandolfi and Stone suggest leadership needs five components to exist-leader(s), follower(s), direction, plan, and objectives. They cite this definition:

A leader is one or more people who selects, equips, trains and influences one or more follower(s) who have diverse gifts, talents and skills and focuses the follower(s) to the organisation's mission and objectives causing the follower(s) to willingly and enthusiastically expend spiritual, emotional and physical energy in a concerted effort to achieve the organisational mission and objectives. (Winston \& Patterson, 2006, cited in Gandolfi \& Stone, 2016, p. 216)

It is easy to critique such definitions as they do not cover the full gamut of leadership contexts; however, trying to create alternative definitions in such a contested field is no easy feat. Gandolfi and Stone (2016) instead go on to highlight the ways in which leadership is discussed across the literature: a) as a process or set of relationships; b) as a combination of personality traits or characteristics; or c) in relation to particular skills and behaviours.

In contrast with the proliferation of research on generic leadership, Hannah et al. (2009) claim that leadership in crisis or extreme 
contexts is one of the least researched areas in the leadership field. In their review of leadership in extreme events, they summarise a crisis as having these features: a) low probability; b) threatening matters of high priority; c) occurring with limited time to respond and d) "characterized by ambiguity of cause, effect, and means of resolution" (p. 899).

The crisis-leadership literature also offers a range of definitions, depending on the sector in which the research is situated, such as business, education, or politics. Alkharabsheh et al. (2013), when discussing a military context, for example, define it this way: "Crisis leadership denotes a set of actions undertaken by a leader to bring about immediate change in people's behaviour as well as to achieve needed outcomes" (p. 282); whereas Boin et al. (2010), drawing on leadership during Hurricane Katrina, use this definition: "Effective crisis leadership entails recognizing emerging threats, initiating efforts to mitigate them and deal with their consequences, and, once an acute crisis period has passed, re-establishing a sense of normalcy" (p. 706). Porche (2009), however, differentiates crisis leadership from crisis management. Crisis management is more operational, including processes such as diagnosis, decision making, and resource mobilisation. Crisis leadership has oversight of crisis management but also provides a vision, direction, and big-picture thinking.

My review of the crisis-leadership literature revealed the sources falling into two groups: a) literature that expounds, sometimes through theoretical discussion and at other times personal commentary, on what effective crisis leaders should do; and b) research-based literature that tries to makes sense of what effective leaders in crisis contexts actually did do. It is the second type that I particularly focus on. As well as providing definitions, the literature tends to set out lists of the traits or behaviours of effective crisis leaders. Figure 1 shares some of these examples. 


\begin{tabular}{|c|c|}
\hline Traits or characteristics & Behaviours or processes \\
\hline $\begin{array}{l}\text { - Adaptable } \\
\text { - Empathetic } \\
\text { - Prepared } \\
\text { - Resilient } \\
\text { - Transparent } \\
\text { - Trustworthy }\end{array}$ & $\begin{array}{l}\text { - Recognising a crisis is coming } \\
\text { - Mount a response } \\
\text { - Develop a network of teams } \\
\text { - Elevate leaders } \\
\text { - Demonstrate empathy } \\
\text { - Communicate effectively } \\
\quad \text { D'Auria and De Smet (2020) }\end{array}$ \\
\hline $\begin{array}{l}\text { - Relationship-oriented } \\
\text { - Participative } \\
\text { - Innovative } \\
\text { - Problem-solver } \quad \text { Alkharabsheh et al. (2013) }\end{array}$ & $\begin{array}{l}\text { - Provide stability, reassurance, confidence and } \\
\text { a sense of control } \\
\text { Alkharabsheh et al. (2013) }\end{array}$ \\
\hline \multirow{3}{*}{$\begin{array}{l}\text { - Trusted } \\
\text { - Respected } \\
\text { - Decisive } \\
\text { - Calm } \\
\text { - Visible } \\
\text { - Accessible } \\
\text { - Mission-focused } \\
\text { - Visionary } \\
\text { - Autonomous } \\
\text { - Selfless } \\
\text { - Committed } \\
\text { - Confident } \\
\text { - Positive } \\
\text { - Strong } \\
\text { - Knowledgeable } \\
\text { - Experienced Porche (2009) }\end{array}$} & $\begin{array}{l}\text { - Integration of prior knowledge, leadership } \\
\text { acumen, and practical experience } \\
\text { - Manage complex tasks simultaneously } \\
\text { Porche (2009) }\end{array}$ \\
\hline & $\begin{array}{l}\text { - Manage their emotions } \\
\text { - Make connections to shared values } \\
\text { - Be proactive } \\
\text { - Act positively, sincerely, and respectfully } \\
\text { Rego and Garau (2007) }\end{array}$ \\
\hline & \multirow{2}{*}{$\begin{array}{l}\text { - Understand the unpredictable nature of } \\
\text { crises } \\
\text { - Being able to lead a decision-making process } \\
\text { - Communicating effectively } \\
\text { - Taking the big picture into account } \\
\text { - Looking for creative solutions } \\
\text { - Being flexible } \\
\text { - Having realistic expectations } \\
\quad \text { Kielkowski (2013) }\end{array}$} \\
\hline $\begin{array}{l}\text { Formal leaders have: } \\
\text { - decision-making skills } \\
\text { - ability to remain calm } \\
\text { - effective communication } \\
\text { - Informal leaders have: } \\
\text { - } \text { motivation to lead } \\
\text { - } \text { autonomy } \\
\text { - emotional leadership } \\
\text { - } \text { and see crisis as opportunity Zhuravsky (2013) }\end{array}$ & \\
\hline
\end{tabular}

Figure 1. A sample of crisis-leadership literature lists of traits and behaviours 
When I first encountered these kinds of lists, although interesting in themselves, I could not see how helpful they would be for me in trying to create an analytic framework for my findings, so I looked in more depth at some of the case studies of leaders who faced crises and coped successfully. Such case studies included Jeffery Greenberg's account of leading his team through the September 11 attacks (Greenberg, 2002), Murray Burton supporting his school through the tragedy of losing a group of students and their instructor on a field trip (Tarrant, 2011a, 2011b), or Robin Kielkowski helping an institution through Superstorm Sandy (Kielkowski, 2013). I also included studies of more than one leader in a crisis context such as Porche (2009) who investigated leadership during Hurricane Katrina, Argenti (2002), who studied business leaders affected by 9/11, and Zhuravsky (2013) who followed formal and informal leaders in a hospital ICU context. These real-life examples brought the abstract lists to life and gave a richer sense of the complexity and fluidity of the situation they faced and the need for constant consideration of the human dimension.

\section{Crisis leadership: A conceptual model}

From such case studies and the wider literature, I created a model that synthesised the traits and processes into three attribute sets. I could then use this model to make sense of the actions of the principals in my Canterbury earthquake study (see Mutch, 2015a). The attribute sets answer three questions: What do crisis leaders bring to their role; how do they prepare for eventualities by building and sustaining key relationships; and, what do they do as the crisis unfolds? 


\begin{tabular}{|l|l|}
\hline $\begin{array}{l}\text { Dispositional } \\
\text { Relational }\end{array}$ & $\begin{array}{l}\text { What leaders bring to the event from their background, personal qualities, } \\
\text { experiences, values, beliefs, personality traits, skills, areas of expertise, and } \\
\text { conceptions of leadership. } \\
\text { The ways in which leaders offer a unifying vision and develop a sense } \\
\text { of community within the organisation, engendering loyalty, enabling } \\
\text { empowerment, building strong and trusting relationships, and fostering } \\
\text { collaboration. } \\
\text { How leaders assess the situation as it unfolds, understanding the context, being } \\
\text { aware of different responses (including cultural sensitivities), making timely } \\
\text { decisions, adapting to changing needs, making use of resources (both material } \\
\text { and personnel), providing direction, responding flexibly, thinking creatively, and } \\
\text { constantly reappraising the options. }\end{array}$ \\
\hline
\end{tabular}

Figure 2. Three sets of crisis-leadership attributes

\section{Crisis leadership: Stories from the field}

Across the different sites I investigated, leaders told me that they felt ill-prepared for the crisis events they faced. In some situations, they had detailed emergency plans, had practised relevant drills, and even engaged with their organisations or communities in preparing for possible occurrences. Yet when the crisis hit, the plans were left on the shelf. The event rarely happened in the way that was expected and leaders were left making it up as they went along. Even in settings that had experienced prior disasters or crises, the learning from one experience did not always carry over to the next. When the initial response was over, they were also not prepared for the hard, ongoing grind of recovery or the long-term consequences of the major event and its subsequent secondary repercussions. In order to get a deeper sense of their experience, I now provide examples from my studies matched against the sets of attributes.

\section{Dispositional attributes}

Many of the crisis leaders I interviewed were able to articulate the values and beliefs that underpinned their leadership practice. Whether they were a New Zealand school principal drawing on Māori values of arohanui and manakitanga, or an NGO leader 
drawing on his faith and service to the community, they had a clear sense of what drove them as a leader. A Japanese principal did not see his own family for many days after the tsunami, because he believed his first duty was to his students and the community members who sought shelter with them. A New Zealand principal talked of the importance of her school having "a culture of care" with "values of persistence, respect, care and curiosity" (Principal C, in Mutch, 2015a, p. 192). ${ }^{1}$ Another New Zealand principal highlighted the importance of humility: "Principals [as crisis leaders] don't think about themselves. They don't tell people what they've done. They just need to know that they are doing the right thing" (Principal A, in Mutch, 2015a, p. 192). One community leader said that, in retrospect, he would be clearer with his team about the organisation's mission and values:

What are our core values, our core components to our understanding of aid and disaster, our understanding of Civil Defence? Let's make sure we get those right. Then what is the next thing we can offer? And work on what we can offer, and what we can do to the best of our ability.

Having a clear sense of their leadership style and a willingness to learn more were strong traits. An NGO leader expressed his approach in a way that Gandolfi and Stone (2016) would characterise as "servant leadership", where leaders have a participatory approach and view leadership as service to others. A New Zealand principal explained her approach this way: "It [the disaster] has shown me the power of real leadership. It put all the theory into practice, especially relational trust" (Principal A, in Mutch, 2015a, p. 192).

1 Where the participant quotations have appeared in a prior publication, this is acknowledged with in-text referencing; where they are not acknowledged, this will be the first time they are formally published. 
The literature suggests that being visible and able to emanate calm are important skills that would be needed in a crisis event. One New Zealand principal displayed this quality when the earthquake hit: "I put on my principal's smile. Parents arrived and were standing outside. I realized then that I had an audience and my response needed to be calm and instantaneous. I had to look like I was in control” (Principal, School NZ1, in Mutch, forthcoming).

Finally, relevant experience can be a valuable attribute. One school from the original Canterbury study went on to experience further trauma from the 2016 Kaikōura earthquakes and, in 2018, a major fire at the school. The following year, students at the school lost a family member in the 2019 mosque attacks. After the fires, the principal realised he could capitalise on his experience of how the school coped with earlier events:

With the fire, the community was saddened again and it did bring back a lot of memories from the earthquakes. Our community and people outside our community wanted to help in some way. The healing part of what we needed to do with the children who were in the classes affected took us back to how we had handled the grief process after the earthquakes. (Principal, in Mutch et al., 2020, p. 149)

\section{Relational attributes}

The attributes model highlights the importance of leaders offering a unifying vision that promotes key values within their organisation. A New Zealand principal highlighted that having an agreed set of values paid off over the long term for his school:

We've got some really strong values and beliefs but now the children are thinking about living them a lot more than they had before the quakes-particularly arohanui, which is caring for people, being there for others and making sure that people are feeling okay or if they need someone to be with. They are really resilient and want to help. (Principal B, in Mutch, 2015b, p. 49) 
Another key attribute is building a sense of community. A New Zealand local council leader highlighted the importance of building togetherness between the different sectors, agencies, geographic, and cultural interests. In some of their communities, this attribute had been neglected and led to tensions between different stakeholder groups as the crisis proceeded but where they had engaged in community building and had strong prior relationships they were able to mobilise response and support more quickly.

Building strong relationships and good teams prior to a crisis event within and beyond the organisation is also key. Some teams already sit within an organisation, as with school senior leadership teams. A New Zealand principal saw the value of collegial team building:

On the day [of the earthquake], the leadership team kicked in and they were making sure the right thing happened. The training and up-skilling really worked for the school. They worked calmly and there was no personal heroism. The deputy principal, the assistant principals and team leaders went and did what was needed at the time. The administrative leader, who is also part of the leadership group, knew to go to the gate and meet parents and tell them to stay calm. (Principal A, in Mutch, 2015b, p. 49)

Other leaders need to call on prior relationships outside their organisation, and in the case of one Nepalese principal, outside his own country:

After the earthquake, I came to realise that most of the students in the affected area lost everything. Their houses were collapsed. They lost their books and their uniforms, some even lost their parents. I asked my Rotary friends in Australia to raise some funds to help the victimised families. (Principal, School N1, in Mutch, forthcoming)

As the crisis continues, leaders also need to live out the values they espouse by displaying care and compassion to those they are 
responsible for. A principal from Vanuatu explains what he did after the 2015 cyclone:

It was one big challenge for me because I've never been through this before. I wanted to meet with the teachers to tell them that the cyclone has passed but we [the school] have been affected. But I have to give time to my teachers because some of them have lost their own houses so I have to accept that they can't come to school if they are busy at home. (Principal, School V1, in Mutch, forthcoming)

Leaders also took on the wider responsibility of their employees' families. A business leader talked about the help he provided after the Canterbury earthquakes:

So, we did a lot of work in terms of just making sure families had resources, money, basic things like water. We arranged a tanker of water. We had a whole lot of supplies organised, and then, obviously, there were all the arrangements for people that were killed and injured and just managing the whole process.

Leaders also had to turn their attention to the people they served, their clients, or in the case of schools, their students. A Nepalese principal explains how he helped his students:

We started a mobile school system. Because I saw that my students were frightened and sad. They had no food and nothing to do and their parents were busy with rescue work. I mobilise my teachers and we go to different places for one or two or three days. We let the children do drawing and painting and singing and dancing to make them happy. We feed them a small snack. We did more than 50 places. (Principal, School N1, in Mutch, forthcoming)

\section{Contextual attributes}

The disaster and crisis literature breaks the response and recovery phases into smaller steps, acknowledging that not every step is a step forward (see, for example, Mutch, 2020). There is usually an 
immediate response period that requires quick thinking. Here is one New Zealand school principal at the time of the 22 February 2011 Canterbury earthquake:

I was just walking out into the playground and BANG! So, the response from me was: 'Right, what do we need to do here? We need to make sure the children know where to go and to go there immediately and not back to their rooms.' So, we set off the alarm and the children were assembled in our assembly area. (Principal, in Mutch, 2018, p. 344)

Next, leaders need to ensure that the teams they have in place for their everyday business will work for the situation they are now facing. Not everyone may be present, available, or have the right skill set. Leaders might need to confirm, reallocate, or create new roles. A local district council, for example, needed to bring together a new crisis-response team. In compiling the team, they looked for a balance of experience and fresh ideas and a combination of big-picture and small-details people.

The crisis-leadership team is then tasked with deciding on a plan of action. A business leader after the Canterbury earthquakes tells his story:

So, I led the recovery of the business here and one of my old colleagues, who was the ex-CEO came back and managed all the families of the deceased. We had a floor plan of 50 people, we had 30 in the building that were trapped, 10 of those were killed, 10 were seriously injured -2 double amputees ... and just huge emotional damage. We lost all our records, all our systems, and so we had a huge rebuild job.

Managing the flow of communication both in and out is important, as one principal notes: "We were communicating with staff in a variety of ways, through emails and texts and the team leader was communicating via the communication trees. And lots 
of communicating with parents" (Principal A, in Mutch, 2015a, p. 192).

Crisis leaders need to balance immediate and critical decision making with taking a big-picture and long-term view. I call this "zooming in and zooming out" (Mutch, 2020, p. 5).

An NGO leader in a disaster context realised that he needed to step back from being hands-on to taking a broader perspective:

You know, in warfare, you need someone up the mountain looking down seeing what's happening because if you're down on the ground you cannot see the big picture. And we had too many people on the ground making decisions - and I'm one of thoseworking the area that you're working in, doing the best that you can but you do not always see the big picture.

The small details still need to be managed. Several principals talked of dealing with practicalities: "I had a dilemma, if I couldn't get into the school then we couldn't get it ready. So, the caretaker and I bought hard hats and wore sensible shoes and organised electricians, plumbers and builders to re-open the school" (Principal A, in Mutch, 2015a, p. 192). A Vanuatu principal did similarly: "After the cyclone, I have to be a carpenter. I look at the classrooms and make a report. The Ministry came around to assess the damage. I ask parents to assist as I have no handyman" (Principal, School V1, in Mutch, forthcoming).

The crisis-leadership role is all-consuming. In order to not burn out, leaders need to take time to pause and slow down:

You need some calm time to stop, to talk to yourself about what has happened. To work out what you want to say and how you are going to say it. You are going to have to explain to children what will happen next and how things are going to get fixed. You need to find some time for yourself to reflect on everything. (Principal B, in Mutch, 2015b, p. 48) 
At the end, they can review their successes and evaluate the lessons they have learnt:

A sense of community is gold - not only in good times but in bad times because you've built up that trust. When things go wrong they look to you for support and advice. That would be my main piece of advice-to have strong values, to live those values, to talk about them and use them to bring your community into your school. (Principal, in Mutch et al., 2020, p. 149)

\section{Crisis leadership: What matters in the context of COVID-19?}

As we observe the range of crisis responses in our own organisations, nationally and internationally, how can we use the literature and the model to evaluate what crisis leadership attributes matter at this time?

\section{Dispositional attributes}

In preparation for crises that any leader might face, Rego and Garau (2007) suggest that they first appraise their personal skills and limitations. Crisis leaders are encouraged to think deeply about the responsibility they have as leaders. Several writers claim that the most successful leaders have a sense of humility (D'Auria \& De Smet, 2020; Gandolfi \& Stone, 2016; Gigliotti, 2017)—a quality displayed by many of the leaders in my study. As Gandolfi and Stone (2016, p. 218) note:

When leaders encourage followers and recognise their contributions, it takes the spotlight off the leader and displays a genuine sense of humility that is not characteristic and typical of many leadership styles that exist in today's complex world.

Hannah et al. (2009) highlight empathy, integrity, and trustworthiness as important traits while Porche (2009) suggests leaders should be transparent and selfless. The insights into the leaders in my study 
certainly bear this out. D'Auria and De Smet (2020) note that experience is valuable but "character is of utmost importance" (p. 4). Crisis leaders, for example, are expected to be adaptable, resilient, calm, and accessible, using their strengths to good effect while acknowledging and mitigating their limitations (Gigliotti, 2017; Porche, 2009).

Rego and Garau (2007) suggest that leaders should then hone the necessary skills needed for a crisis situation. Communication is one of the most vital skills needed in a crisis context (Argenti, 2002; D’Auria \& De Smet, 2020; Kielkowski, 2013; Mutch, 2015a). It is important to provide frequent updates, be clear about what is known and not known, and to address audience concerns and questions (D’Auria \& De Smet, 2020). In my studies, I noted that effective leaders often took over the key communication role themselves or delegated it to someone else who could do it competently. They simultaneously managed the communication coming in and communication going out, adjusting their messages as new information came to hand.

Allied to communication is keeping on top of the flow of information (Argenti, 2002; Tarrant, 2011a, 2011b). In the current crisis, there is often criticism of a leader who makes a decision then modifies the decision or changes direction as new information comes to hand. When they try to explain the reason for the change, they are accused of "flip-flopping" or "justifying after the fact". Flexibility and agility in the fast-moving crisis environment are skills that should be admired, not denigrated. Crisis leaders need to show that they have the necessary skills to manage the fast flow of information, the constantly changing evidence, and the ability to distil contradictory advice from experts and advissrs (Argenti, 2002; Kielkowski, 2013).

Crisis leaders need a consistent, recognisable, and credible leadership approach. Alkharabsheh et al. (2013) compared transformational and transactional leadership styles in crises. Transformational styles 
focus on inspiring towards a higher collective purpose whereas transactional leaders focus on managing complex operating procedures. They concluded that the style is not as important as providing stability, confidence, reassurance, and a sense of control. De Bussy and Paterson (2012), on the other hand, found transformational leadership to be highly effective in a crisis context but harder to sustain over the long term, especially once a sense of normalcy had returned. In the end, what is more important than the particular style is that the leader is able to "detach from a fraught situation and think clearly about how [they] will navigate it ..." all the while displaying "deliberate calm", and "visible decisiveness" (D’Auria \& De Smet, 2020, pp. 4-5).

\section{Relational attributes}

My study highlights the importance of the human dimension of crisis leadership. D'Auria and De Smet (2020) suggest that dealing with the human tragedy is a leader's first priority. In order to do this successfully, being relationship-oriented is key (Alkharabsheh et al., 2013). This includes valuing individuals and building strong relationships and networks prior to any crisis (Argenti, 2002; Gandolfi \& Stone, 2016; Hannah et al., 2009; Mutch, 2015a, 2015b).

Both in the literature and in my studies, building and sustaining mutual trusting and respectful relationships made the leader's crisis response flow more smoothly. Having an agreed purpose, vision, set of values, and way of operating meant that it was easier to determine priorities, allocate roles, and have everyone spring into action (Argenti, 2002; Mutch, 2015b). As Argenti (2002, p. 104) notes from his research into the aftermath of September 11:

But if 9/11 taught us anything, it's that we can't anticipate every contingency. Sometimes, we have no choice but to improvise ... Improvisation, after all, is most effective when a strong corporate mission and vision are already in place to inform and guide it. 
Building a collective culture means that the sense that "we are all in this together" can mitigate response and recovery processes being poorly implemented, undermined, or ignored. People pull together more willingly if they have been absorbing the organisation's vision and principles as part of their everyday activities and interactions (Argenti, 2002; Mutch, 2015b; Mutch et al., 2020).

D'Auria and De Smet (2020) also discuss the idea of elevating leaders. They do not mean putting them on a pedestal, but in recognising that, while many crisis leaders are formal leaders with titles, it is also important to recognise (and elevate) emerging leaders who bring the right mix of knowledge, skills, experience, and presence that is needed in the unfolding context. Zhuravsky (2013) notes that, while formal leaders might have oversight and management of the crisis, informal leaders are often highly motivated, emotionally attuned, and see the crisis as an opportunity to step up. They can make a substantial contribution to the crisis resolution.

\section{Contextual attributes}

While dispositional and relational attributes are important at any time, contextual attributes-being able to read the situation and respond appropriately_are even more important during times of crisis. These are the behaviours and processes that were found in many of the lists in the literature (see Figure 1). Boin et al. (2010), for example, highlight recognising threats, initiating efforts to mitigate them, dealing with the consequences, and re-establishing some sense of normality.

One of the first important contextual attributes is being able to overcome normalcy bias, (Boin et al., 2010); that is, being able to see that what is looming is not a normal occurrence that will pass but has unusual characteristics that mean we need to take it seriously and set processes in place to deal with what might eventuate. While it is not 
possible to anticipate an earthquake, for example, we can clearly see the differences in the ways that world leaders have responded to the COVID-19 threat. In some cases, despite mounting evidence, they ignored the signs and avoided taking advice from experts.

Being able to lead teams through a decision-making process is also one of the contextual attributes highlighted (D'Auria and De Smet, 2020; Kielkowski, 2013; Mutch, 2015b). D’Auria and De Smet (2020, p. 4) suggest that, "Crisis-response leaders must be able to unify teams behind a single purpose". They continue: "Leaders should foster collaboration and transparency across the network of teams. One way they do this is by distributing authority and sharing information: in other words, demonstrating how the teams themselves should operate" (p. 4).

One of the key findings from my research, supported by the literature, was that crises play out in unexpected ways (Argenti, 2002; D’Auria \& De Smet, 2020; Greenberg, 2002; Kielkowski, 2013; Mutch, 2015a). While having done some emergency planning was helpful, especially in team building and role allocation (Greenberg, 2002; Mutch, 2015b), it could not always be relied upon in the fast-moving, fluid, and sometimes chaotic situation that presented itself. Kielkowski's (2013) experience of Superstorm Sandy led to highlighting the importance of being flexible and looking for creative solutions in the face of such unpredictability as important contextual attributes.

\section{Crisis leadership: Using the model in our evaluation and lead- ership practice}

In this article, I have provided examples from my own research and the crisis-leadership literature to support the crisis-leadership attributes model as a way of understanding what leaders do under pressure. Figure 3 sets out possible evaluative questions from the 
model that could be used to contribute to conducting a self-evaluation of our own leadership in these uncertain times or in making an evaluative judgement of crisis leaders near and far in the context of the current pandemic. Looking to the future, the questions could also play a part in leadership development and appraisal to prepare leaders for future crises.

\begin{tabular}{|c|c|c|}
\hline Attribute & Description & Evaluative questions \\
\hline $\begin{array}{l}\text { Dispositional: } \\
\text { What do crisis } \\
\text { leaders bring } \\
\text { to their role? }\end{array}$ & $\begin{array}{l}\text { What leaders } \\
\text { bring from their } \\
\text { background, } \\
\text { personal qualities, } \\
\text { experiences, } \\
\text { values, beliefs, } \\
\text { personality traits, } \\
\text { skills, areas of } \\
\text { expertise, and } \\
\text { conceptions of } \\
\text { leadership. }\end{array}$ & $\begin{array}{l}\text { What do leaders see as their strengths? In what ways do they } \\
\text { display these strengths (e.g., adaptability, integrity)? How do } \\
\text { others see their strengths? } \\
\text { Do they use their strengths to good effect? Are their } \\
\text { strengths honed for a crisis situation (e.g., is information } \\
\text { communicated clearly and effectively)? } \\
\text { Are they conscious of their limitations? Do they take steps to } \\
\text { mitigate their limitations (e.g., upskilling, delegating)? How } \\
\text { do others view their ability to discern their strengths and } \\
\text { limitations? } \\
\text { Do they appear to have a recognisable and credible } \\
\text { leadership style? Can they articulate and justify their } \\
\text { approach? Do they demonstrate that they have thought } \\
\text { deeply about what leadership is? To what extent do others } \\
\text { find that they portray a consistent and confidence-inspiring } \\
\text { approach? }\end{array}$ \\
\hline $\begin{array}{l}\text { Relational: } \\
\text { How do } \\
\text { crisis leaders } \\
\text { prepare for } \\
\text { eventualities } \\
\text { by building } \\
\text { and } \\
\text { sustaining } \\
\text { key } \\
\text { relationships? }\end{array}$ & $\begin{array}{l}\text { The ways in } \\
\text { which crisis } \\
\text { leaders offer a } \\
\text { unifying vision } \\
\text { and develop } \\
\text { a sense of } \\
\text { community } \\
\text { within the } \\
\text { organisation, } \\
\text { engendering } \\
\text { loyalty, enabling } \\
\text { empowerment, } \\
\text { building strong } \\
\text { and trusting } \\
\text { relationships, } \\
\text { and fostering } \\
\text { collaboration. }\end{array}$ & $\begin{array}{l}\text { Do crisis leaders provide a vision that resonates with those } \\
\text { they are leading? In what ways have they built a collective } \\
\text { culture that is inclusive and responsive rather than reactive } \\
\text { and divisive? } \\
\text { In what ways do leaders build trust, reinforce values, and } \\
\text { communicate these values effectively? } \\
\text { What is the strength of the relationships and networks built } \\
\text { prior to a crisis situation? How do leaders draw on these } \\
\text { relationships to support or inform their crisis response? } \\
\text { In what ways do leaders display the value of sustaining key } \\
\text { relationships, whether they were built prior to the event or } \\
\text { needed to be established because of the event? } \\
\text { How successful are they in bringing and keeping the } \\
\text { organisation or community together beyond the initial } \\
\text { response phase? } \\
\text { How do leaders nurture the strengths and abilities of } \\
\text { informal and emerging leaders in preparation for, and during, } \\
\text { a crisis event? }\end{array}$ \\
\hline
\end{tabular}




\begin{tabular}{|c|c|c|}
\hline Attribute & Description & Evaluative questions \\
\hline $\begin{array}{l}\text { Contextual: } \\
\text { What do } \\
\text { leaders do } \\
\text { as the crisis } \\
\text { unfolds? }\end{array}$ & $\begin{array}{l}\text { How crisis } \\
\text { leaders assess } \\
\text { the situation } \\
\text { as it unfolds, } \\
\text { understanding } \\
\text { the context, } \\
\text { being aware } \\
\text { of different } \\
\text { responses, } \\
\text { making timely } \\
\text { decisions, } \\
\text { adapting to } \\
\text { changing needs, } \\
\text { making use } \\
\text { of resources, } \\
\text { providing } \\
\text { direction, and } \\
\text { constantly } \\
\text { reappraising the } \\
\text { options. }\end{array}$ & $\begin{array}{l}\text { In what ways do leaders display the necessary skills to lead } \\
\text { a crisis situation (e.g., managing the fast flow of information, } \\
\text { appraising the constantly changing situation and keeping } \\
\text { calm under pressure)? } \\
\text { In what ways do leaders model how to operate in a crisis } \\
\text { environment (e.g., building and sustaining strong teams or } \\
\text { distributing authority as needed)? } \\
\text { How are decisions made? How well do leaders understand } \\
\text { the wider system and the flow-on effects of decisions? } \\
\text { How well do leaders manage complex tasks simultaneously } \\
\text { or balance competing priorities and interests effectively? } \\
\text { Are resources-both material and personnel-used to good } \\
\text { effect? } \\
\text { How well attuned are leaders to the unexpected twists and } \\
\text { turns of the crisis? How are they guiding their organisation } \\
\text { or community through the unpredictability yet providing a } \\
\text { sense of stability and confidence? } \\
\text { To what extent do people come first in the crisis response? } \\
\text { Do leaders show that they have a sense of the big picture } \\
\text { and of short-, medium-, and long-term planning needs and } \\
\text { implications? } \\
\text { How well does the response exemplify the organisation's or } \\
\text { community's vision and values? } \\
\text { How is reflection and evaluation built into the phases of the } \\
\text { response? }\end{array}$ \\
\hline
\end{tabular}

Figure 3: Evaluative questions to use with the crisis leadership attributes

In conclusion, as the COVID-19 pandemic plays out in our lives and on our television screens, do we see current leaders acting as crisis leaders_emanating calm, providing reassurance with a dose of reality, assessing the fast-moving situation, remaining visible, accessible, and engaged, acting decisively, and guiding their teams, organisations, or countries through this pandemic with clarity and compassion? It is easy to be armchair critics, but the purpose of this article is to provide those who are leaders, or who are engaged in leadership development, appraisal, research, or evaluation, a basis on which to make such judgements. Drawing on the literature and my work across six countries, I have provided a framework that highlights three crisis-leadership attribute groups and accompanying questions to guide our work in this emerging field. Understanding 
the characteristics and nuances of crisis leadership is particularly important in this current situation as we manage our way through and beyond the COVID-19 pandemic but also in preparation for any of the unanticipated crises that might beset us in the future.

\section{Acknowledgements}

My thanks go to various funders who supported the different projects that are cited here, in particular, the New Zealand National Commission for UNESCO, The University of Auckland, and the Royal Society of New Zealand/Japan Society for the Promotion of Science. I would also like to thank the anonymous reviewer who provided good advice for restructuring the article. Finally, I would like to thank the crisis leaders who gave their time and shared their stories with me. We are the richer for your generosity.

\section{References}

Alkharabsheh, A., Ahmad, Z., \& Kharabsheh, A. (2013). Characteristics of crisis and decisionmaking styles: The mediating roles of leadership styles. Procedia-Social and Behavioral Sciences, 129(2014), 282-288. https://doi. org/10.1016/j.sbspro.2014.03.678

Argenti, P. (2002). Crisis communication: Lessons from 9/11. Harvard Business Review, (December), 103-109.

Boin, A., 't Hart, P., McConnell, W., \& Preston, T. (2010). Leadership style, crisis response and blame management: The case of Hurricane Katrina. Public Administration, 88(3), 706-723. https://doi. org/10.1111/j.1467-9299.2010.01836.x

D’Auria, G., \& De Smet, A. (2020). Leadership in a crisis: Responding to the coronavirus outbreak and future challenges. McKinsey \& Company [online]. https://www.mckinsey.com/ /media/ McKinsey/Business\%20Functions/Organization/Our\%20Insights/ Leadership \%20in\%20a\%20crisis\%20Responding\%20to\%20 the $\% 20$ coronavirus $\% 20$ outbreak $\% 20$ and $\% 20$ future $\% 20$ challenges/ 
Leadership-in-a-crisis-Responding-to-the-coronavirus-outbreak-andfuture-challenges-v3.pdf

de Bussy, N., \& Paterson, A. (2012). Crisis leadership styles—Bligh versus Gillard: A content analysis of Twitter posts on the Queensland floods. Journal of Public Affairs. Wiley Online Library. https://doi.org/10.1002/ pa. 1428

Gandolfi, F., \& Stone, S. (2016). Clarifying leadership: High-impact leaders in a time of leadership crisis. Review of International Comparative Management, 17(3), 212-224.

Gigliotti, R. (2017). 6 critical components of effective crisis leadership. International Capital Marketing Association [online]. https://icma.org/ articles/article/6-critical-components-effective-crisis-leadership

Greenberg, J. W. (2002). September 11, 2001. A CEO's story. Harvard Business Review, 80(10), 58-64.

Hannah, S. T., Uhl-Bien, M., Ariolo, B. J., \& Cavarretto, F. L. (2009). A framework for examining leadership in extreme contexts. The Leadership Quarterly, 20(2009), 897-919. https://doi.org/10.1016/j. leaqua.2009.09.006

Kielkowski, R. (2013). Leadership during crisis. Journal of Leadership Studies, 7(3), 62-65. https://doi.org/10.1002/jls.21300

Mutch, C. (2015a). Leadership in times of crisis: Dispositional, relational and contextual factors influencing school principals' actions. International Journal of Disaster Risk Reduction, 14(2), 186-194. https://doi. org/10.1016/j.ijdrr.2015.06.005

Mutch, C. (2015b). The impact of the Canterbury earthquakes on schools and school leaders: Educational leaders become crisis managers. Journal of Educational Leadership, Policy and Practice, 3(2), 39-55.

Mutch, C. (2018). The role of schools in helping communities cope with earthquake disasters: The case of the 2010-2011 New Zealand earthquakes. Environmental Hazards, 17(4), 331-351. https://doi.org/10.10 80/17477891.2018.1485547 
Mutch, C. (2020). How might research on schools' responses to earlier crises help us in the COVID-19 recovery process? Set: Research Information for Teachers [online]. https://doi.org/10.18296/set.0169

Mutch, C. (forthcoming). High expectations, low recognition: The role of principals and teachers in disaster response and recovery in the Asia-Pacific. In H. James (Ed.), Risk, resilience and reconstruction: Science and governance for effective disaster risk reduction and recovery. PalgraveMcMillan.

Mutch, C., Miles, J., \& Yates, S. (2020). "River of emotions”: Reflecting on a university-school-community partnership to support children's emotional processing in a post-disaster context. In R. M. Reardon \& J. Leonard (Eds.), Alleviating the educational impact of adverse childhood experiences: School-university-community collaboration (pp. 135-155). Information Age Publishing.

Porche, D. (2009). Emergent leadership during a natural disaster. A narrative analysis of an acute health care organization's leadership. [Unpublished doctoral dissertation, Capella University, Minneapolis, MN].

Rego, L., \& Garau, R. (2007). Stepping into the void. Centre for Creative Leadership.

Tarrant, R. (2011a). Leadership through a school tragedy: A case study. (Part 1-The first week). Australasian Journal of Disaster and Trauma Studies, (3), 65-76.

Tarrant, R. (2011b). Leadership through a school tragedy: A case study. (Part 2-The next two years). Australasian Journal of Disaster and Trauma Studies, (3), 77-87.

Zhuravsky, L. (2013). Crisis leadership in an acute clinical setting: Christchurch Hospital ICU 2011. [Unpublished Master's dissertation, University of Otago, Dunedin]. 


\section{The author}

Carol Mutch is a professor in critical studies in education at The University of Auckland. Her research into the role of schools in disaster response and recovery has earned her a 2020 University of Auckland Research Excellence medal. She is the author of numerous books and journal articles and her contributions to education and educational research have been recognised with national and international awards. She is currently the Education Commissioner for the New Zealand National Commission for UNESCO.

Email: c.mutch@auckland.ac.nz 